1 USE OF LAGRANGIAN SIMULATIONS TO HINDCAST THE GEOGRAPHICAL

2 POSITION OF PROPAGULE RELEASE ZONES IN A MEDITERRANEAN COASTAL

3 FISH

4

5 Antonio Calò ${ }^{1,4 *}$, Christophe Lett ${ }^{2,5}$, Baptiste Mourre $^{3}$, Ángel Pérez-Ruzafa ${ }^{1}$, José Antonio García-

6 Charton $^{1}$

7

$8{ }^{1}$ Departamento de Ecología e Hidrología, Universidad de Murcia, Campus Espinardo, 30100,

9 Murcia, Spain;

10 2Sorbonne Universités, UPMC Univ Paris06, IRD, unité de modélisation mathématique et

11 informatique des systèmes complexes (UMMISCO), F-93143, Bondy, France;

$12{ }^{3}$ Modelling and Forecasting facility, Balearic Islands Coastal Observing and Forecasting System 13 (SOCIB), Palma, Balearic Islands, Spain;

${ }^{4}$ Present address: Université Nice Sophia Antipolis, CNRS, FRE 3729 ECOMERS, Parc Valrose 28,

${ }^{5}$ Present address: UMR MARBEC, Station Ifremer de Sète, Avenue J. Monnet, 34203 Sète Cedex, France

*antoniocalo.es@gmail.com

\title{
24 ABSTRACT
}

25 The study of organism dispersal is fundamental for elucidating patterns of connectivity between 26 populations, thus crucial for the design of effective protection and management strategies. This is especially challenging in the case of coastal fish, for which information on egg release zones (i.e. spawning grounds) is often lacking. Here we assessed the putative location of egg release zones of the saddled sea bream (Oblada melanura) along the south-eastern coast of Spain in 2013. To this aim, we hindcasted propagule (egg and larva) dispersal using Lagrangian simulations with two approaches: 1) back-tracking and 2) comparing settler distribution obtained from simulations to the analogous distribution resulting from otolith chemical analysis. Simulations were also used to 
33 assess which factors contributed the most to dispersal distances. In back-tracking simulations, the 34 majority of particles were moved back in time southward, suggesting that the North-African coasts 35 and the Easter Alboran Sea were hydrodynamically suitable to generate and drive the supply of 36 larvae along the coast of Murcia. With the second approach, a correlation between simulation 37 outputs and field results (otolith chemical analysis) was found, suggesting that the oceanographic 38 characteristics of the study area could have determined the pattern of settler distribution recorded 39 with otolith analysis in 2013. Dispersal distance was found to be significantly affected by the 40 geographical position of propagule release zones. The combination of methods used was the first 41 attempt to assess the geographical position of propagule release zones in the Mediterranean Sea for 42 O. melanura, and can represent a valuable approach for elucidating dispersal and connectivity 43 patterns in other coastal species.

44

45 Key words: propagule release zones, Lagrangian simulations, dispersal distance, sea bream, 46 Mediterranean Sea 


\section{INTRODUCTION}

49 The study of causes and consequences of organism dispersal is crucial from both ecological and evolutionary perspectives (Burgess et al., 2015). It provides vital information on demographic processes, species responses to environmental variability and anthropogenic stresses and on gene flow among populations, which, in turn, affect meta-population dynamics and species local adaptation (Burgess et al., 2015). In the case of fish, dispersal plays a major role in determining the spatial scale over which populations interact genetically and ecologically (i.e. connectivity) and how they should be managed (Grüss et al., 2011; Green et al., 2014). In spite of its great importance, the quantification of dispersal is still a challenging issue. Direct measures of dispersal are made hard by the difficulty to track individuals throughout their life cycle, especially during early developmental stages (Barbee and Swearer, 2007; Cowen, 2007; Calò et al., 2013). Most marine coastal fish species have a complex life cycle including a pelagic propagule (egg and/or larva) phase, that ends with the settlement in benthic habitats, followed by a demersal juvenile/adult phase (Leis et al., 2011). For these fishes, post-settlement stages are considered relatively site attached, so it is the propagule phase that contributes mostly to species dispersal capacity (Leis, 2015), although, in some cases, movement by juveniles (Di Franco et al., 2015) and adults (Aspillaga et al., 2016) can significantly contribute to population connectivity. In this context, a major issue for fish ecologists is the lack of knowledge on the locations where eggs are released (i.e. spawning grounds) (Thorrold et al., 2007). This, together with the minuscule dimension of eggs and larvae, makes it impractical to track propagules from their origins to their destination (i.e. settlement sites) and obtain an exhaustive measure of connectivity during the pelagic phase (Thorrold et al., 2001). The location of egg release zones is only possible through direct observations of spawning events or using acoustic methods, or indirectly through traditional ecological knowledge (e.g. fisherman knowledge about zones of fish massive catches) ( Heyman et al., 2004; Boomhower et al., 2007).

In the last decades, modelling tools based on outputs of water circulation models were developed to simulate particle dispersal. Assuming that propagules are advected and diffused similarly to water particles (Cowen, 2007), Lagrangian-based, spatially-explicit individual-based models (IBMs) have been recognized as powerful tools to track pelagic particles from potential release zones to settlement habitats (Werner et al., 2007; Watson et al., 2010). IBMs have been used both to hindcast and forecast patterns of propagule transport and address challenging ecological questions such as: the assessment of the potential impact of climate change on propagule dispersal (Lett et al., 2010; Andrello et al., 2015b) or to help in the design of MPA networks and in their future management 
82 dispersal and connectivity can be influenced by spatial and temporal variability of different physical 83 and biological factors (Andrello et al., 2013; Ospina-Álvarez et al., 2013; Ospina-Alvarez et al., 84 2015; Tanner et al., 2017), providing crucial information on the factors that drive fish settlement 85 variability and giving support to the development of effective fishery management strategies 86 (Ospina-Alvarez et al., 2015). Model simulations were also used to corroborate results or test 87 hypotheses on propagule dispersal based on complementary methodologies such as genetic analysis 88 or chemical analysis of calcified structures (e.g. (Calò et al., 2013), in the Mediterranean Sea).

89 In 2013, otoliths of juvenile individuals of the saddled sea bream (Oblada melanura) were analysed 90 chemically to identify the number of potential natal sources along the Mediterranean south-eastern 91 coast of Spain (Murcia region). A set of release zones were found to supply a series of coastal sites 92 spread along 180 km of coastline (Calò et al., 2016). Otolith analysis does not allow to assess the 93 geographical position of natal origins. In this context, dispersal simulations could be used to 94 hindcast the position of the propagules' sources previously identified.

95 In the present study we implemented a biophysical IBM to investigate the putative geographical 96 position of propagule release zones of Oblada melanura previously discriminated with otolith 97 chemical analysis, along the south-eastern coast of Spain in 2013. Dispersal simulations were also 98 used to assess the factors more likely to influence propagule dispersal distances in the region. We 99 used species-specific information on early life history traits (ELTs), i.e. spawning dates, pelagic 100 larval duration and settlement dates, of the selected species. This information was gathered in the 101 same spatial and temporal context of the oceanographic data implemented for the simulations. Apart 102 from their ecological importance in the geographic context considered, the results of the study can 103 provide useful insights for the development of new approaches to investigate the location of fish 104 spawning areas. 


\section{Hydrodynamic model}

108 The Western Mediterranean OPerational forecasting system (WMOP, (Juza et al., 2016)) is based on 109 a regional ocean configuration of the ROMS model implemented over the Western Mediterranean 110 Sea (www.socib.es). The ROMS is a free-surface split-explicit model, solving the hydrostatic 111 primitive equations using terrain-following curvilinear vertical coordinates, employing the 112 Arakawa-C horizontal and vertical grid staggering (Shchepetkin and McWilliams, 2005). The 113 WMOP has a horizontal resolution from 1.8 to $2.2 \mathrm{~km}$ and 32 sigma-levels in the vertical 114 dimension, with a spatial coverage from Gibraltar strait to Sardinia Channel $\left(6^{\circ} \mathrm{W}, 9^{\circ} \mathrm{E}, 35^{\circ} \mathrm{N}\right.$, $\left.11544.5^{\circ} \mathrm{N}\right)$. The model is forced by high-resolution winds (5 km, 3 hours) from the Spanish Meteorological Agency. The simulation used in this study is a sample over the period 2013-2014 of

117 a 6.5-year long simulation of WMOP starting in September 2008. Initial and boundary conditions 118 were provided by the CMEMS MED-MFC model.

\section{Larval dispersal model}

121 Daily outputs of three-dimensional velocities fields simulated by WMOP were used to simulate Oblada melanura larval dispersal using the software Ichthyop 3.2 (Lett et al., 2008). The time step of larval transport was set to $100 \mathrm{~s}$ in order to keep it lower than the ratio of cell size to maximum current velocity, so that propagules do not cross more than one cell boundary in a single time step (Courant-Friedrichs-Lewy condition). Given that no information on egg buoyancy nor larval active swimming and vertical migration are available for $O$. melanura, in all the simulations a neutral buoyancy was assigned to eggs and larvae, which were subjected only to current transport (i.e. passive dispersal).

Putative natal origins and settler distribution of Oblada melanura

To locate the major natal origins of $O$. melaura identified along the study area in 2013, two different approaches were used: 1) backtracking propagule dispersal simulations and 2) the comparison between settler distributions obtained from forward model simulations and the pattern recorded from post-settler otolith chemistry by (Calò et al., 2016)). Running the larval dispersal model in backtracking mode allowed to explore those areas where it was hydrodynamically possible for propagules to be transported toward the coastal sites in which juveniles were sampled in 2013. Micro-structural analyses performed on the otoliths of pre-settlers individuals of $O$. melanura (i.e. larval individuals, sampled close to the coast, that are in the last phase of larval phase) indicated that the mean age of larvae (days after hatching), immediately 
140 before settlement, was 11.5 days in 2013 (Calò et al. unpublished data). This measure of larval 141 duration was 2 days shorter than the standard pelagic larval duration (PLD) as measured with the 142 analysis of otoliths of individuals that had already settled. For this reason, the dispersal duration 143 used for the backtracking simulation was 13.5 days, i.e. the sum of the mean days after hatching 144 plus 2 days of egg phase duration. The choice to use a shorter measure of larval duration was made 145 in order to exclude the last days of larval life (i.e. the competency phase) in which behavioural and 146 movement capabilities are likely developed (Leis, 2007). Moreover, shortening the dispersal 147 duration has proven to determine similar effects to introducing some larval behaviour in the model, 148 reducing the effect of considering propagules as passive particles (Andrello et al., 2013) (Andrello 149 et al., 2017). In backward simulations, particles released from a backward-time-release-zone started 150 their 'virtual life' with a positive age (i.e. 13.5 days) and became younger as the simulation moves 151 towards completion (as simulated time retreats/regresses). Nine backward-time-release-zones were 152 distributed along the coast, in correspondence to the locations where settlers were sampled in 2013 153 for otolith chemical analysis (Figs 1a and b). Particles were released following the settlement dates 154 of $O$. melanura recorded in 2013. Eight simulations were run covering all sampled dates moving 155 backward in time from July $14^{\text {th }}$ to July $7^{\text {th }}$. In each simulation 1,000 particles were released from 156 each backward-release-zone, a number which was initially tested as being large enough to cover all 157 possible origins of the particles.

158 For the second approach, the settler distribution recorded along the coast in 2013, as resulted from 159 otolith chemical analyses (Calò et al., 2016), was tested against a series of settler distributions 160 resulting from different Ichthyop runs. In these forward simulations, particles released from 161 forward-time-release-zones started their 'virtual life' with age $=0$ and grow older as the simulation 162 moves towards completion (as simulated time progresses/advances). In each model run, forward163 release-zones were randomly selected from a set of potential release zones distributed along the 164 coast. Previous results from otolith chemical analyses (Calò et al, 2016) showed the presence of 5 165 major natal origins (here considered as a proxy of egg release zones) that supplied 17 coastal sites 166 in 2013. In order to compare these results with Ichthyop simulation outputs, settler distribution data 167 from the 17 sites were pooled, by couples of neighbouring sites, into 9 locations (apart from site 7 , 168 Fig. 1a and b). In Ichthyop, 13 potential release zones were created: 9 were located in 169 correspondence to the 9 'pooled locations' of the otolith study (named from L1 to L9, Fig. 1b), 2 170 zones were located immediately outside the sampled area (O1 and O2) and 2 other zones were 171 positioned inside the study area (M1 and M2). These last 4 zones were created for better covering 172 the whole domain. The zones L1-L9 (Fig. 1b) were used as settlement zones (the same 9 zones 173 being used in the backtracking experiment). All the release and settlement zones had the same 174 surface. Fifty Ichthyop simulations (of the possible 1287) were run, each with 5 release zones 
175 randomly selected from the set of 13 potential release zones. The duration of dispersal phase used

176 for running the model was the mean 13.5 days, as for backward simulations. In all simulations, we considered a spawning depth range of $0-20 \mathrm{~m}$, which is where larvae of $O$. melanura are more commonly found (Sabatés et al., 2007). The spawning dates recorded for O. melanura in 2013 179 (from June $21^{\text {th }}$ to July $2^{\text {nd }}$ ), were used for daily release, accounting for $95 \%$ of all the spawning dates recorded in 2013 (Calò et al unpublished data). Two hundred particles were released for each zone and date, for a total of 12,000 particles per simulation ( 200 particles $\times 5$ zones $\times 12$ dates). In Ichthyop the 'stop when recruited' option was turned on, i.e. particles were assumed to settle and stop moving when passing over a settlement zone, and considering a minimum age for settling of 10 days, that was the minimum age found for pre-settlement individuals of O.melanura in 2013 (Calò et al unpublished data). After each model run, the distribution of propagules that settled in the 9 settlement zones was used to generate a data frame with 5 variables (release zones) and 9 replicates (settlement zones). Each value of the data frame represented the ratio of propagules settled in one of the 9 settlement zones, released from each of the 5 random release zones, divided by the total number of settling propagules from each release zone. A Mantel's test based on $10^{6}$ permutations (performed with 'ade4' package, R software) was used to investigate which model-generated settler distributions were significantly correlated to the analogous distribution obtained from otolith analysis (built with the 5 major natal origins and the 9 'pooled locations'). Before performing Mantel's tests, a distance matrix (based on Euclidean distance) was created from each data frame. After the first 50 simulations, the release zones that produced statistically significant Mantel's tests (8 of the original 13, see Results) were used for running new Ichthyop runs with the same simulation settings as before but covering all the 56 possible combinations of 5 natal sources (in the possible 8). Simulation outputs were tested against the data frame resulting from otolith analysis using Mantel's test as described above.

199 Finally patterns of settler distributions generated from simulations that produced statistically significant Mantel's tests were analysed and compared to the pattern recorded from otolith chemical analysis. For model-generated settler distributions, the local retention, defined as the fraction of propagules released from a zone that settled back to the same zone, was also assessed.

\section{Dispersal distance of Oblada melanura}

To investigate the factors contributing to propagule dispersal of O. melanura along the coast of the Murcia region, the distance from the release point to the final point at the end of larval transport was measured for each simulated larva as the great-circle distance (i.e. the shortest distance between two points on a sphere). Three release zones were selected from the set of 13 release zones previously considered in the forward simulations: L1, L5 and M2 respectively in the north, centre 
210 and south of the study area. These zones host three MPAs of the region, respectively from north to 211 south: Tabarca MPA (established in 1986), Cabo de Palos MPA (established in 1995) and Cabo 212 Tiñoso MPA (established in 2016). Given that no information on the exact spawning depth range of 213 O. melanura is available, we considered 4 different release depth ranges: $0-5 \mathrm{~m}, 5-10 \mathrm{~m}, 10-15 \mathrm{~m}$ 214 and 15-20m. Two different propagule dispersal durations were considered as resulted from otolith 215 micro-structural analysis: the mean days after hatching (11.5 days), i.e. the mean larval duration 216 recorded for larvae sampled close to the coast immediately after settlement, and the mean PLD (14 217 days), i.e. the measure of larval duration recorded for individuals that had already settled. An 218 Ichthyop simulation was run for each combination of depth ranges (4) and dispersal durations (2), 219 resulting in a total of 8 runs. In each run 30 particles were released in each of the 3 release zones 220 and following the spawning period recorded in O. melanura in 2013 , i.e. from June $21^{\text {th }}$ to July $2^{\text {nd }}$ 221 for a total of 12 releasing dates. A high consistency between simulation runs repeated under the 222 same software configuration and parameter values was observed during preliminary analyses, 223 indicating that the number of released particles was sufficient to provide robust simulated patterns. 224 Model outputs were merged together creating a data frame containing 720 dispersal distance values 225 (4 depth ranges $\times 2$ dispersal durations $\times 3$ zones $\times 30$ particles). To test for potential differences in 226 dispersal distances related to the position of the spawning zone, depth and the duration of propagule 227 dispersal phase, an analysis of variance (ANOVA) was performed, considering the factors 'Release 228 zone' (Z) (random, with 3 levels), 'Depth range' (D) (fixed, with 4 levels crossed to Z), and 229 'Dispersal duration time' (T) (fixed, with 2 levels, PLD vs. DAH, crossed to Z and D). There were 23030 replicate distance values (one for each simulated propagule) per each combination of levels of 231 the three factors considered. Before performing ANOVA, data were tested for homogeneity of 232 variance using Chocran's test, finding no evidence of heterogeneity of variance in all cases 233 ( $\mathrm{p}>0.05$ ). ANOVA was run using the GAD package in $\mathrm{R}$ software ( $\mathrm{R}$ Development Core Team, 234 2013). 


\section{RESULTS}

\section{Putative natal origins and settler distribution of Oblada melanura}

238 Backward simulations showed that most particles were transported southward (Fig. 2).

239 Nevertheless, in two simulations, corresponding to the release dates $14^{\text {th }}$ and $13^{\text {th }}$ of July, an inshore

240 accumulation of propagules was recorded along a stripe between release zones 2 and 4, in the north

241 of the study area (Figs. 2 a and b). In both cases these particles originated from backward-time-

242 release-zone L3. In two other simulations (release dates $10^{\text {th }}$ and $9^{\text {th }}$ of July, Figs. 2 e and f), an

243 inshore accumulation of propagules, also originated from backward-time-release-zone L3, was 244 observed in the north of the study area, in proximity of Tabarca MPA.

245 Concerning forward simulations from randomly selected sets of forward-release zones (second 246 approach), the 5 random release zones selected for each of the first 50 model runs and the 247 associated Mantel's tests are reported in Table S1 (Supplementary Material). Among all Mantel's 248 tests performed between the settler distribution resulting from otolith chemical analysis and the 249 Ichthyop-generated settler distributions, two tests (Ichthyop runs \#3 and \#28) were statistically 250 significant $(\mathrm{p}<0.05)$, indicating a correlation between field data and model simulation outputs 251 (Table S1, Supplementary Material). The forward-release zones that produced these 2 statistically 252 significant Mantel's tests (O1, L1, L2, L3, L5, M2, L9 and O2) were combined in sets of 5 and used 253 for the second group of 56 model runs (thus, release zones M1, L4, L6, L7 and L8 were excluded 254 from the second set of simulations). From this second group of simulations, 8 new runs (out of 10, 255 considering the previous two) produced settler distributions significantly correlated (Mantel's test: $256 \mathrm{p}<0.05$ ) to the analogous settler distribution resulting from otolith chemical analysis (Table S2, 257 Supplementary Material).

258 For these 10 runs, the settler distribution in the 9 'pooled locations' from the 5 major natal origins 259 are shown in Fig. 3b-k aside the distribution resulted from otolith chemical analysis (Fig. 3a). 260 Release zones L2 and O2 were present 9 times; zones O1, L1, L5, M2, L9 were present from 5 to 7 261 times; while L3 was present 3 times (Fig. 3 b-k). Considering these 10 simulations, the mean 262 percentage of local retention was $29.9 \%$ (average from release zones L1 to L9 over all dates), with 263 the highest values (46.3\%) recorded in L2 and the minimum (1.2\%) recorded in L5. Propagules 264 released from L2 supplied almost all the settlement zones considered. Propagules released in L2 265 settled predominantly within L2 (i.e., were retained locally) and settlement decreased in areas with 266 increasing distance from L2 (Fig 3b, d, e, f, j, k). The same pattern applies to L3 and L9 (except 267 Fig. 3e). Simulated settled propagule distribution was different between the northern and the 268 southern sector of the study area, with release zones in the north (O1, L1, L2, and L3) only 269 supplying the northern and the central settlement zones while the opposite was observed for 
270 propagules released from the southern zones (L5, M2, L9, O2; Fig. 3).

271

272 Dispersal distance of Oblada melanura

273 Simulated dispersal distances ranged from 1 to $197 \mathrm{~km}$ with a mean value of $55.2 \mathrm{~km}$ considering 274 all model runs. Short dispersal distances were more common than longer ones: 62\% dispersed 275 between 0 and $50 \mathrm{~km}, 17 \%$ between 50 and 100km, 15\% between 100 and 150km and 6\% between 276150 and $200 \mathrm{~km}$ (Fig. 4). A significant interaction between factors 'Z' (release zone) and 'D' (depth 277 range) was detected (Table 1), so that the effect of depth on dispersal distances depended on the 278 release zone. Indeed, for the three selected zones, dispersal distance tended to increase with depth, 279 but this increase was strong in Tabarca, weak in Cabo Tiñoso, whereas in the case of Cabo de Palos 280 a difference in dispersal distance was only found between the shallowest depth level (0-5 m) and the 281 others (Fig. 5). Overall, distances obtained for particles released in Cabo de Palos (88.2 $\pm 3.1 \mathrm{~km}$, 282 mean \pm SE) were greater than for those released from Tabarca $(44.2 \pm 2.8 \mathrm{~km})$ and from Cabo 283 Tiñoso $(33.1 \pm 1.8 \mathrm{~km}$ ) (Fig. 5). No effect of dispersal duration was found in the range of tested 284 values (Table 1). 
287 The geographical location of fish propagule release zones is considered by fish ecologists as one of 288 the hardest issues to solve. Here we adopted two approaches to hindcast the putative location of $O$. 289 melanura propagule release zones along the coast of the Murcia region.

290 The first approach (back-ward simulations) was used to assess which zones had the optimal 291 hydrodynamic characteristics to originate and drive the supply of larvae sampled in 2013. 292 Simulations conducted backward in time showed that the majority of propagules could have 293 originated in areas tens of kilometres southward. The transport of particles towards the southern 294 sector of the Alboran Sea suggests that the North-African coast could potentially host spawning 295 grounds of $O$. melanura. From this perspective, the distance between the Algerian coast and the 296 south-eastern Spanish coast (150-200 km) is comparable to the distance that the saddled sea bream 297 is able to cover during the propagule phase (Calò et al, 2016). In some backward simulations, a 298 portion of propagules was moved back in time toward coastal areas that can potentially sustain adult 299 populations of $O$. melanura., in particular the northern sector of the study area, from zone L4 to 300 zone L2 (Tabarca marine reserve). These zones are characterised by extended patches of sea grass 301 beds (mainly composed by Posidonia oceanica) disposed along the coast (Sánchez-Lisazo, 1993); 302 (Calvin Calvo et al., 1999) that represent optimal habitats for hosting reproductive populations of 303 saddled sea bream. Moreover, in the absence of any information on the reproductive habits of the 304 saddled sea bream it is not possible to exclude a priori that offshore sectors of the Eastern Alboran 305 Sea could host reproductive grounds of this species.

306 In the second approach, we considered the set of natal origins discriminated by otolith chemical 307 analysis of juvenile individuals collected in 2013 (Calò et al., 2016) and evaluated their putative 308 geographical position along the study area. The results showed that ten simulations, run using 309 different sets of release zones, produced settled propagule distributions that were significantly 310 correlated to the analogous observed settler distribution. Generally, these simulations included 311 similar release zones, with 2 zones (L2 and O2) present in almost all the simulations, demonstrating 312 consistency among model outputs.

313 In the simulated propagule distributions, for most release zones, the fraction of settled propagules 314 was highest in the zone itself and decreased with increasing distance from each zone. This pattern is 315 in agreement with the spatial correlation among frequencies of settlers sharing the same natal origin 316 observed in (Calò et al., 2016). The identification of the exact geographical position of the natal 317 origins found with otolith chemical analysis is extremely difficult using currently available 318 methodologies. Thus, it is hard to establish whether the spatial dependency characterising settler 319 frequencies found in (Calò et al., 2016) is the consequence of a distance-dependent dispersal from 
320

321

322

323

324

325

326

327

328

329

330

331

332

333

334

335

336

337

338

339

340

341

342

343

344

345

346

347

348

the spawning areas. However, the concordance with simulation outputs allows us to hypothesize the putative position of the natal origins identified from otolith analysis. For model-generated distributions, the highest fraction of settled propagules was generally recorded inside or in the proximity of the corresponding release zone: for the release zones L2 (Tabarca marine reserve), L3 and L9 the highest fraction of settled propagules corresponded to local retention, while in the case of O1, M2 (Cabo Tiñoso MPA) and O2 the highest fraction settled in the closest zone. Only in the case of L1 and L5 (Cabo de Palos marine reserve) a partial southward shift was recorded between the release zones and the settlement zones where the highest frequencies of settling propagules were recorded. These results suggest that, in certain sectors of the study area, the pattern of currents could have promoted a distance-dependent dispersal from release zones, with short dispersal distances more likely to occur than longer ones. From these considerations, we speculate that some of the main natal origins identified in juvenile individuals caught in 2013, based on otolith microchemistry, could have been located inside or in proximity of the zones where the highest fractions of settlers were recorded. Release zone L2 (Tabarca island) could be of critical importance for $O$. melanura in the region considered as it was present in almost all model simulations that produced significant correlations with otolith results, and it was also the zone supplying the majority of settlement zones. Concurrently, in this zone the highest frequency of settlers sharing the same natal origin was recorded (Fig. 3a). As stated before, this zone was also identified in the backward simulations. Therefore, zone L2 could likely host one of the natal origins identified with otolith analysis. Noticeably, this zone hosts the marine reserve of Tabarca, an effective MPA (Lozano Quijada and Ramos-Esplá, 2015), with coastal habitats mainly characterised by shallow rocky bottoms and P. oceanica sea grass beds (Ramos-Esplá, 1985). Propagule distribution from model simulations also showed a clear separation between the northern and the southern sectors of the study area: propagules released from northern zones rarely reached settlement zones in the south of the study area and vice versa. This outcome is concordant with the significant difference in settler natal origin composition identified between the two sectors, using otolith chemical analysis (Calò et al., 2016). The resemblance between simulation outputs and field results from otolith analysis suggests that small and mesoscale oceanographic features, like coastal eddies, could have played a major role in shaping settler distribution of $O$. melanura along the study area. The formation of mesoscale eddies (MEs, with a diameter of 50-100 km) is frequent along the stretch of coastline considered (Millot, 1999), and was also observed in the simulations carried out in this study. Recent studies highlighted that MEs may represent important habitats for the larval stages of coastal fishes, due to increased primary and secondary productivity (Nakata et al., 2000) (Sabatés et al., 2007) (Shulzitski et al., 2015) (Sabatés et al., 2013). There are evidences that larvae entering MEs grow consistently faster than those outside the eddies, consequently leading to lower mortality rates and 
355 higher successful settlement in coastal habitats (Shulzitski et al., 2015). MEs could also be 356 responsible for larval patch formation in the pelagic environment, supporting the results on patch 357 cohesiveness recorded in the study area, based on otolith analysis of larvae (Calò et al, 2016) consisting in that groups of larvae originating from different natal origins could merge during their larval phase. From this perspective, even in the absence of behavioural traits or active movements, the formation of heterogeneous larval patches can be promoted by water mixing structures in different moments of the pelagic phase. In the model implemented here, we considered larvae as passive particles, including no behavioural or movement capabilities, thus potentially biasing our model outputs (Leis, 2007) (Leis et al., 2011). On the other hand, by shortening the dispersal duration implemented (i.e. using the DAH instead of the PLD) we prevented running the model during the competency phase of the saddled sea bream (Calò et al. unpublished data), thus reducing the potential influence of behaviour and active movements that characterise the last moment of the larval phase (Leis, 2007). In addition, the use of proper information on ELTs (i.e. spawning dates, propagule larval duration), gathered at the same spatial and temporal context of the oceanographic data, allowed us to improve the accuracy of the simulated dispersal.

The spatial scale of dispersal recorded here is in accordance with the estimation obtained from otolith chemical analysis of O. melanura for the same spatial and temporal context (Calò et al., 2016). Results from dispersal simulations showed that dispersal distance depended mainly on spatial factors. The geographical position of release zones was also found responsible of larval dispersal distance variability in other recent works (Treml et al., 2015) (Thomas et al., 2014). In our study, propagules released in the centre of the study area (Cabo de Palos MPA) dispersed twice further than those released in the northern and southern zones, probably due to the oceanographic characteristics of the region. The northern half of the study area is characterised by an extended continental shelf ( $\sim 300 \mathrm{~km}$ from the coast) and shallow waters $(0-200 \mathrm{~m})$. In the southern sector the continental shelf is very narrow and the continental slope, cut through by a series of coastal canyons, is only few thousands of meters distant from the coast (Calvin Calvo et al., 1999). Cabo de Palos marine reserve is geographically located in the transition between these two morphologically different areas and the oceanographic circulation in its surroundings reflects these geomorphological features, determining strong currents compared to the northward and southward coastal sectors of the study area. This pattern was clearly highlighted by averaging current velocities in the study area over the time window in which simulations were run (i.e. $21^{\text {st }}$ June 2013 $-15^{\text {th }}$ July 2013) (Fig. 6, 1-4). From this point of view, the southward shift in the distribution of settled propagules released from zone L5 (i.e. Cabo e Palos MPA) reported above, could be a consequence of the strong current dynamic characterising the area around Cabo de Palos (Fig 6, 1- 
particles released in shallow waters dispersed less in average than those released deeper in the 3 release zones considered. This outcome contradicts the general assumption that current velocities tend to decrease with depth. However, the particular oceanographic conditions characterising the study area are likely responsible for this dispersal pattern, with deeper waters moving faster than shallow ones (Fig. 6, a and b). This difference is probably due to coastal recirculation characteristics, for example the formation of coastal eddies. These oceanographic features are related to wind forcing and are consequently more pronounced at the surface than in deeper water layers. The analysis of model runs with different release depths shows that the formation of a relatively wide recirculation system trapped a large number of particles close to the surface, while particles released in deeper water were only partially affected by the eddy and followed longer paths southward (Fig. 7). Considering the significant influence of depth on propagule dispersal distances, any biological process may be important to be considered in future work. From this perspective, the collection of information on egg buoyancy, larval behaviour and movement of the saddled sea bream would allow to improve the simulations run in this study.

The significant variability in dispersal distances due to spatial factors could have blurred the effect of dispersal duration, here found non-significant. Although the relation between propagule dispersal and its duration in the pelagic environment is currently a matter of debate (Shanks, 2009) (Leis et al., 2013), it is generally accepted that fish dispersal distance is positively correlated with dispersal duration. In this work, however, the relatively short time of dispersal and the small difference between the two dispersal durations (2.5 days) could have determined the lack of significant variability of the temporal factor. Moreover, the frequent occurrence of small and medium-size coastal eddies along the study area could have contributed to the observed result. Propagules that enter an eddy could remain trapped inside it, blurring the effects of different dispersal times. The variability of propagule dispersal in this geographical context and associated with the depth of

414 release suggests that even for species with a short propagule dispersal phase ( $\sim 14$ days in the case of O. melanura), local differences in oceanographic conditions can lead to a wide range of dispersal outcomes.

417 Information on the location of fish spawning grounds and the scale of dispersal is crucially 418 important for elucidating connectivity patterns between populations, and for providing the optimal 419 background knowledge in order to design efficient protection and management strategies. The 420 method used here, combining model simulations with information on natal origin composition 421 resulting from otolith chemical analysis, supported by accurate information on fish biological traits, 422 is a first attempt to locate fish release zones in the Mediterranean Sea. The approach implemented 423 could provide valuable results for the localization of fish spawning grounds for other species, 424 especially considering the current lack of methodological alternatives for addressing this issue 
425 worldwide.

426

427 ACKNOWLEDGMENTS

428 This research was supported by the European project 'Initial Training Network for Monitoring 429 Mediterranean Marine Protected Areas' (MMMPA: FP7-PEOPLE-2011-ITN) [grant number 430 290056]. 
Andrello, M., Guilhaumon, F., Albouy, C., Parravicini, V., Scholtens, J., Verley, P., Barange, M., Sumaila, U.R., Manel, S., Mouillot, D., 2017. Global mismatch between fishing dependency and larval supply from marine reserves. Nat. Commun. doi:10.1038/ncomms16039

Andrello, M., Jacobi, M.N., Manel, S., Thuiller, W., Mouillot, D., 2015a. Extending networks of protected areas to optimize connectivity and population growth rate. Ecography (Cop.). 38, 273-282. doi:10.1111/ecog.00975

Andrello, M., Mouillot, D., Beuvier, J., Albouy, C., Thuiller, W., Manel, S., 2013. Low connectivity between Mediterranean marine protected areas: a biophysical modeling approach for the dusky grouper Epinephelus marginatus. PLoS One 8, e68564. doi:10.1371/journal.pone.0068564

Andrello, M., Mouillot, D., Somot, S., Thuiller, W., Manel, S., 2015b. Additive effects of climate change on connectivity between marine protected areas and larval supply to fished areas. Divers. Distrib. 21, 139-150. doi:10.1111/ddi.12250

Aspillaga, E., Bartumeus, F., Linares, C., Starr, R.M., López-sanz, À., Díaz, D., Zabala, M., Hereu, B., 2016. Ordinary and Extraordinary Movement Behaviour of Small Resident Fish within a Mediterranean Marine Protected Area. PLoS One 11, 1-19. doi:10.6084/m9.figshare.3188587

Barbee, N., Swearer, S., 2007. Characterizing natal source population signatures in the diadromous fish Galaxias maculatus, using embryonic otolith chemistry. Mar. Ecol. Prog. Ser. 343, 273282. doi:10.3354/meps06886

Boomhower, J.P., Romero, M. a, Posada, J.M., Kobara, S., Heyman, W.D., 2007. Identification of Reef Fish Spawning Aggregation Sites in Los Roques Archipelago National Park, Venezuela. Proc. 60th Gulf Caribb. Fish. Inst.

Burgess, S.C., Baskett, M.L., Grosberg, R.K., Morgan, S.G., Strathmann, R.R., 2015. When is dispersal for dispersal? Unifying marine and terrestrial perspectives. Biol. Rev. n/a-n/a. doi:10.1111/brv.12198

Calò, A., Di Franco, A., De Benedetto, G., Pennetta, A., Pérez-Ruzafa, Á., García-Charton, J., 2016. Propagule dispersal and larval patch cohesiveness in a Mediterranean coastal fish. Mar. Ecol. Prog. Ser. 544, 213-224. doi:10.3354/meps11609

Calò, A., Félix-Hackradt, F.C., Garcia, J., Hackradt, C.W., Rocklin, D., Treviño Otón, J., Charton, J. a. G., 2013. A review of methods to assess connectivity and dispersal between fish populations in the Mediterranean Sea. Adv. Oceanogr. Limnol. 4, 150-175. doi:10.1080/19475721.2013.840680

Calvin Calvo, J.C., Franco Navarra, I., Marín Atucha, A., Belmonte Ríos, A., Ruiz Fernandez, J.M., 1999. El litoral sumergido de la region de murcia. Cartografía bionómica y valores ambientales.

Cowen, R.K., 2007. Population Connectivity in Marine Systems. Oceanography 20, 14-21. doi:10.1126/science.1122039

Di Franco, A., Calò, A., Pennetta, A., De Benedetto, G., Planes, S., Guidetti, P., 2015. Dispersal of larval and juvenile seabream: Implications for Mediterranean marine protected areas. Biol. Conserv. 192, 361-368. doi:10.1016/j.biocon.2015.10.015 
Green, A.L., Maypa, A.P., Almany, G.R., Rhodes, K.L., Weeks, R., Abesamis, R. a., Gleason, M.G., Mumby, P.J., White, A.T., 2014. Larval dispersal and movement patterns of coral reef fishes, and implications for marine reserve network design. Biol. Rev. 90, 1215-1247. doi:10.1111/brv.12155

Grüss, A., Kaplan, D.M., Guénette, S., Roberts, C.M., Botsford, L.W., 2011. Consequences of adult and juvenile movement for marine protected areas. Biol. Conserv. 144, 692-702. doi:10.1016/j.biocon.2010.12.015

Heyman, W.D., Azueta, J., Lara, O., Majil, I., Neal, D., Luckhurst, B., Paz, M., Morrison, I., Rhodes, K.L., Kjerve, B., Wade, B., Requena, N., 2004. Protocolo para el monitoreo de agregaciones reproductivas de peces arrecifales en el Arrecife Mesoamericano y el Gran Caribe.

Juza, M., Mourre, B., Renault, L., Gómara, S., Sebastian, K., López, S.L., Borrueco, B.F., Beltran, J.P., Troupin, C., Tomás, M.T., Heslop, E., Casas, B., Tintoré, J., 2016. Operational SOCIB forecasting system and multi-platform validation in the Western Mediterranean. J. Oper. Oceanogr. 9231. doi:10.1002/2013JC009231.

Leis, J., 2007. Behaviour as input for modelling dispersal of fish larvae: behaviour, biogeography, hydrodynamics, ontogeny, physiology and phylogeny meet hydrography. Mar. Ecol. Prog. Ser. 347, 185-193. doi:10.3354/meps06977

Leis, J.M., 2015. Is dispersal of larval reef fishes passive?, in: Mora, C. (Ed.), Ecology of Fishes on Coral Reefs. Cambridge University Press, pp. 223-226.

Leis, J.M., Caselle, J.E., Bradbury, I.R., Kristiansen, T., Llopiz, J.K., Michael, J., O’Connor, M.I., Paris, C.B., Shanks, A.L., Sogard, S.M., Swearer, S.E., Treml, E.A., Vetter, R.D., Warner, R.R., 2013. Does fish larval dispersal differ between high and low latitudes ? Proc. R. Soc. Biol. Sci. 280.

Leis, J.M., van Herwerden, L., Patterson, H.M., 2011. Estimating connectivity in marine fish populations: what works best?, in: Oceaography and Marine Biology: An Annual Review. pp. 193-234.

Lett, C., Ayata, S.-D., Huret, M., Irisson, J., 2010. Biophysical modelling to investigate the effects of climate change on marine population dispersal and connectivity. Prog. Oceanogr. 87, 106113.

Lett, C., Verley, P., Mullon, C., Parada, C., Brochier, T., Penven, P., Blanke, B., 2008. A Lagrangian tool for modelling ichthyoplankton dynamics. Environ. Model. Softw. 23, 1210-1214. doi:10.1016/j.envsoft.2008.02.005

Lozano Quijada, F., Ramos-Esplá, A.A., 2015. Nueva Tabarca, un desafío multidisciplnar.

Millot, C., 1999. Circulation in the Western Mediterranean Sea. J. Mar. Syst. 20, 423-442. doi:10.1016/S0924-7963(98)00078-5

Nakata, H., Kimura, S., Okazaki, Y., Kasai, A., 2000. 120042 Implications of meso-scale eddies caused by frontal disturbances of the Kuroshio Current for anchovy recruitment. J. Mar. Sci. 57, 143-152. doi:10.1006/jmsc.1999.0565 
Ospina-Álvarez, A., Bernal, M., Catalán, I.A., Roos, D., Bigot, J.L., Palomera, I., 2013. Modeling Fish Egg Production and Spatial Distribution from Acoustic Data: A Step Forward into the Analysis of Recruitment. PLoS One 8, 1-18. doi:10.1371/journal.pone.0073687

Ospina-Alvarez, A., Catalán, I. a., Bernal, M., Roos, D., Palomera, I., 2015. From egg production to recruits: Connectivity and inter-annual variability in the recruitment patterns of European anchovy in the northwestern Mediterranean. Prog. Oceanogr. 138, 431-447. doi:10.1016/j.pocean.2015.01.011

R Development Core Team, 2013. R: A Language and Environment for Statistical Computing, R Foundation for Statistical Computing Vienna Austria.

Ramos-Esplá, A., 1985. Tabarca, La reserva marina de la Isla Plana o Nueva.

Sabatés, A., Olivar, M.P., Salat, J., Palomera, I., Alemany, F., 2007. Physical and biological processes controlling the distribution of fish larvae in the NW Mediterranean. Prog. Oceanogr. 74, 355-376. doi:10.1016/j.pocean.2007.04.017

Sabatés, A., Salat, J., Raya, V., Emelianov, M., 2013. Role of mesoscale eddies in shaping the spatial distribution of the coexisting Engraulis encrasicolus and Sardinella aurita larvae in the northwestern Mediterranean. J. Mar. Syst. 111-112, 108-119. doi:10.1016/j.jmarsys.2012.10.002

Sánchez-Lisazo, J.L., 1993. Estudio de la pradera de Posidonia oceanica (L.) Delile de la reserva marina de Tabarca (Alicante): Fenología y producción primaria. Dep. Ciències Ambient. i Recur. Nat.

Shanks, A.L., 2009. Pelagic Larval Duration and Dispersal Distance Revisited. Biol. Bull. 216, 373-385.

Shchepetkin, A.F., McWilliams, J.C., 2005. The regional oceanic modeling system (ROMS): a splitexplicit, free-surface, topography-following-coordinate oceanic model. Ocean Model. 9, 347404. doi:10.1016/j.ocemod.2004.08.002

Shulzitski, K., Sponaugle, S., Hauff, M., Walter, K., D’Alessandro, E.K., Cowen, R.K., 2015. Close encounters with eddies: oceanographic features increase growth of larval reef fishes during their journey to the reef. Biol. Lett. 11, 20140746. doi:10.1098/rsbl.2014.0746

Tanner, S.E., Teles-machado, A., Martinho, F., Peliz, Á., Cabral, H.N., 2017. Modelling larval dispersal dynamics of common sole ( Solea solea ) along the western Iberian coast. Prog. Oceanogr. 156, 78-90. doi:10.1016/j.pocean.2017.06.005

Thomas, Y., Dumas, F., Andréfouët, S., 2014. Larval dispersal modeling of pearl oyster pinctada margaritifera following realistic environmental and biological forcing in ahe atoll lagoon. PLoS One 9. doi:10.1371/journal.pone.0095050

Thorrold, S., Zacherl, D., Levin, L., 2007. Population Connectivity and Larval Dispersal Using Geochemical Signatures in Calcified Structures. Oceanography 20, 80-89. doi:10.5670/oceanog.2007.31

Thorrold, S.R., Latkoczy, C., Swart, P.K., Jones, C.M., 2001. Natal homing in a marine fish 
548 Treml, E.A., Ford, J.R., Black, K.P., Swearer, S.E., 2015. Identifying the key biophysical drivers, 549 connectivity outcomes, and metapopulation consequences of larval dispersal in the sea. Mov. $550 \quad$ Ecol. 3, 17. doi:10.1186/s40462-015-0045-6

551 Watson, J.R., Mitarai, S., Siegel, D.., Caselle, J.E., Dong, C., McWilliams, J.C., 2010. Realized and 552 potential larval connectivity in the Southern California Bight. Mar. Ecol. Prog. Ser. 401, 31553 48. doi:10.3354/meps08376

554 Werner, F.E., Cowen, R.K., Paris, C.B., 2007. Coupled biological and physical models: present $555 \quad$ capabilities and necessary developments for future studies of population connectivity. $556 \quad$ Oceanography 20, 54-69. 


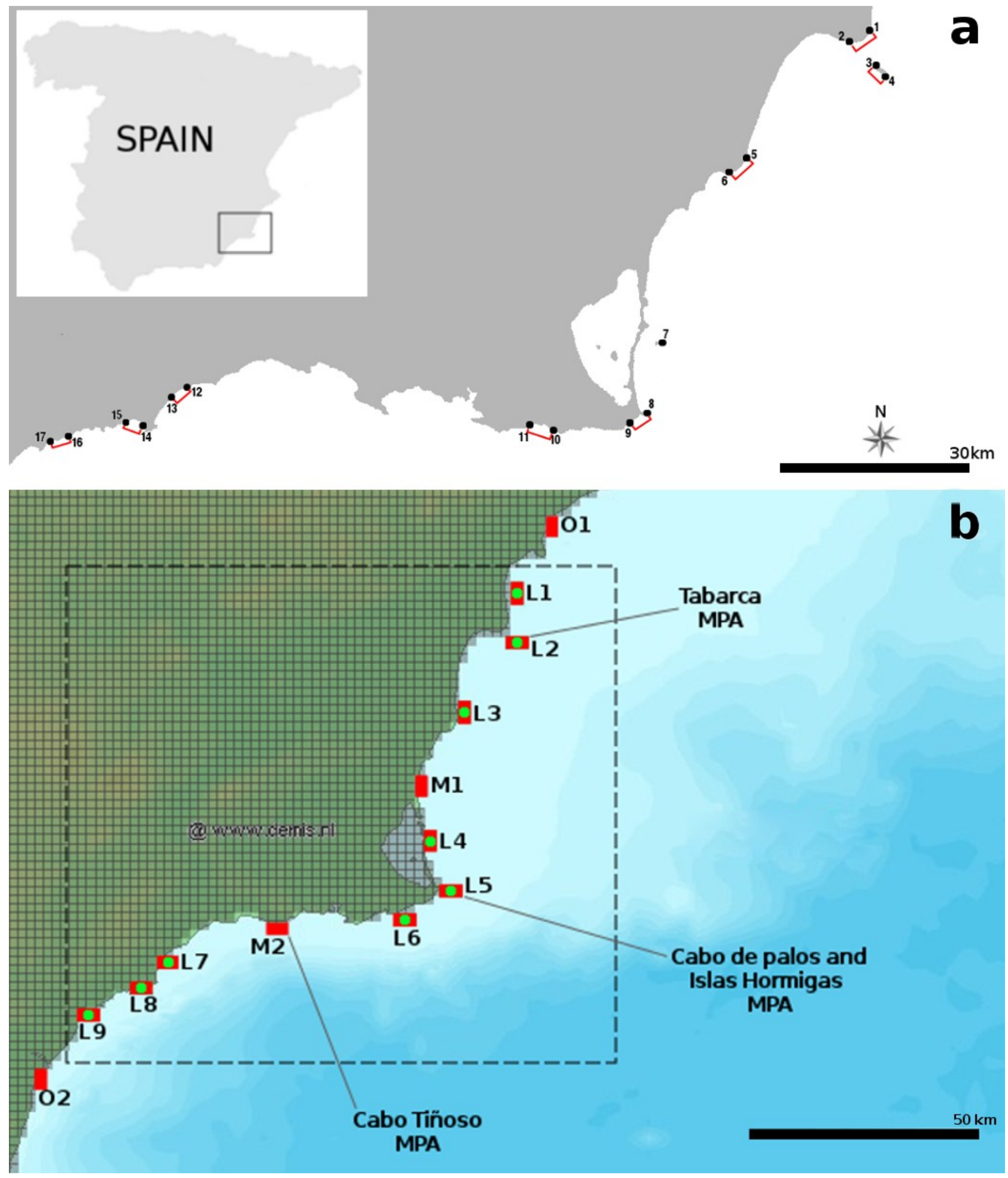

559 Figure 1. a) Study area considered in the work on otolith chemical analysis (Calò et al., 2016): black 560 dots represent the 17 sites sampled, red segments link pairs of sites pooled for creating the 'pooled 561 locations' used in the present study; b) Domain considered in simulations: red rectangles represent 562 the 13 potential release zones used, green dots mark the 9 settlement zones representing the 'pooled 563 locations' shown in (a); the dashed rectangle encloses the study area shown in (a). Zones L2, L5, 564 and M2 include Marine Protected Areas (MPAs). 

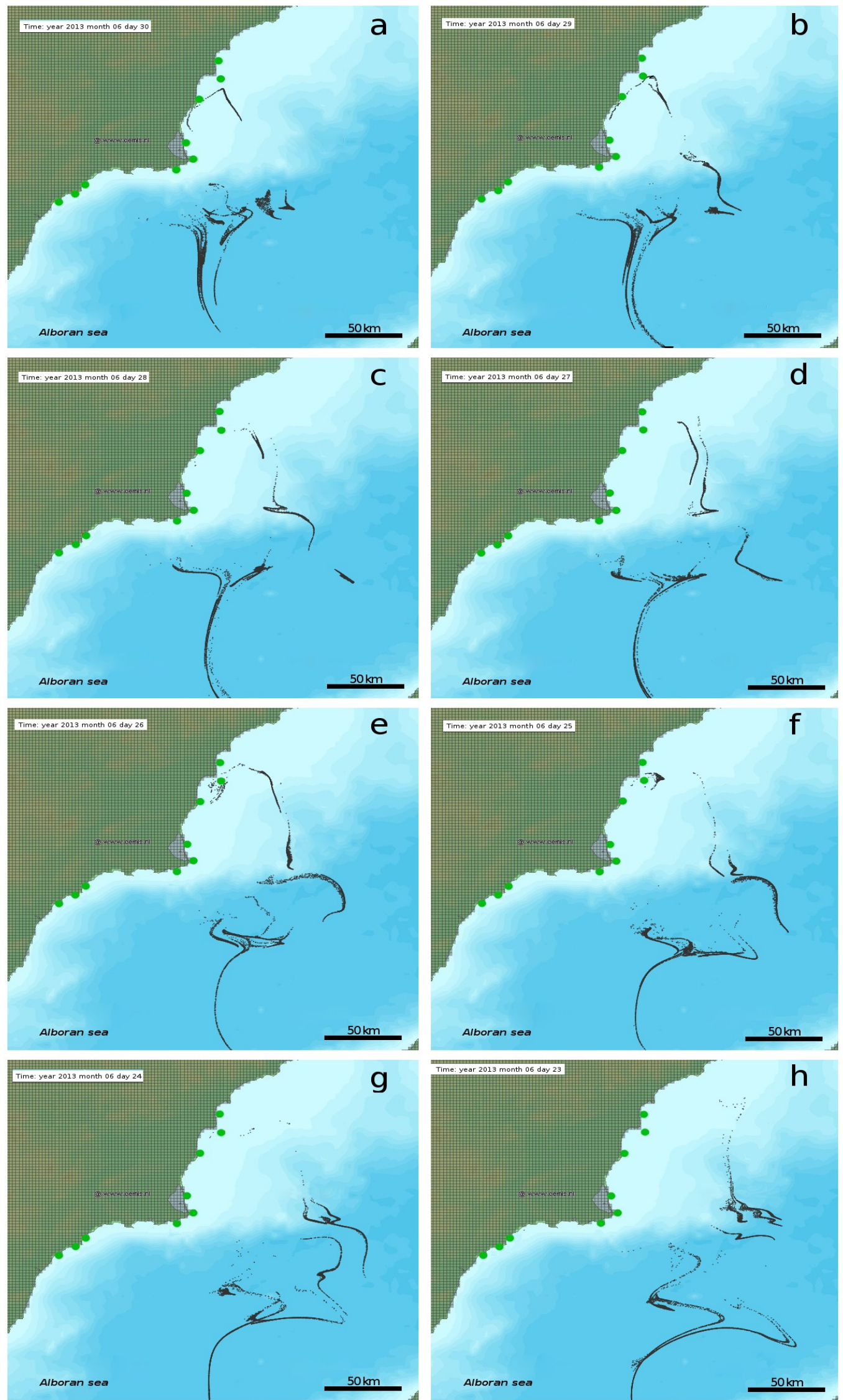

565 Figure 2. Dispersal patterns obtained from backtracking simulations. Each panel represents the final 566 step of each of the 8 simulations run backward with a different release date: from July $14^{\text {th }}$ (a) to 567 July $7^{\text {th }}(\mathrm{h})$. Black dots represent simulated propagules. Green dots represent release zones. 
568 Figure 3. Percentage of $O$. melanura settlers/particles from natal origin/release zone. a) Results 569 from otolith chemical analysis: settler distribution in the 9 'pooled locations' from the 5 major natal
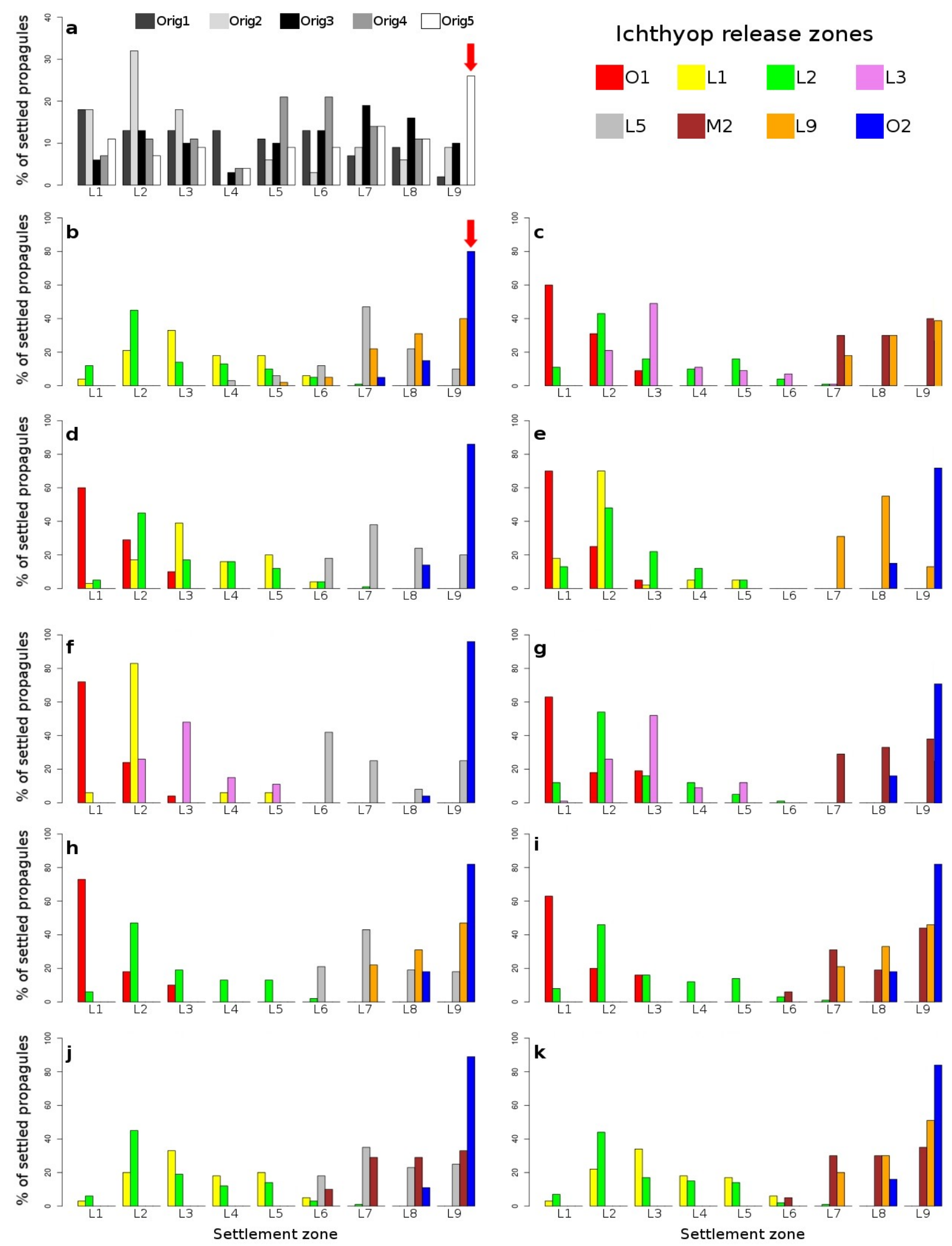

570 origins (grey scale) identified by (Calò et al., 2016); as an example, the white bar indicated by the

571 red arrow shows that $\sim 30 \%$ of the propagules identified from unknown origin 5 were collected in 572 zone L9; b)-k) Propagule distributions in the 9 settlement zones as resulted from larval dispersal 
573 simulations using different sets of release zones (here taken as putative spawning areas, i.e., the red 574 rectangles in Fig. 1b). Only simulated propagule distributions that were significantly correlated with 575 the distribution obtained from otolith chemical analysis (panel a) are shown (See Tab. S2 for 576 details). As an example, the blue bar indicated by the red arrow in panel b shows that $\sim 80 \%$ of the 577 individuals released in zone $\mathrm{O} 2$ settled in zone L9 


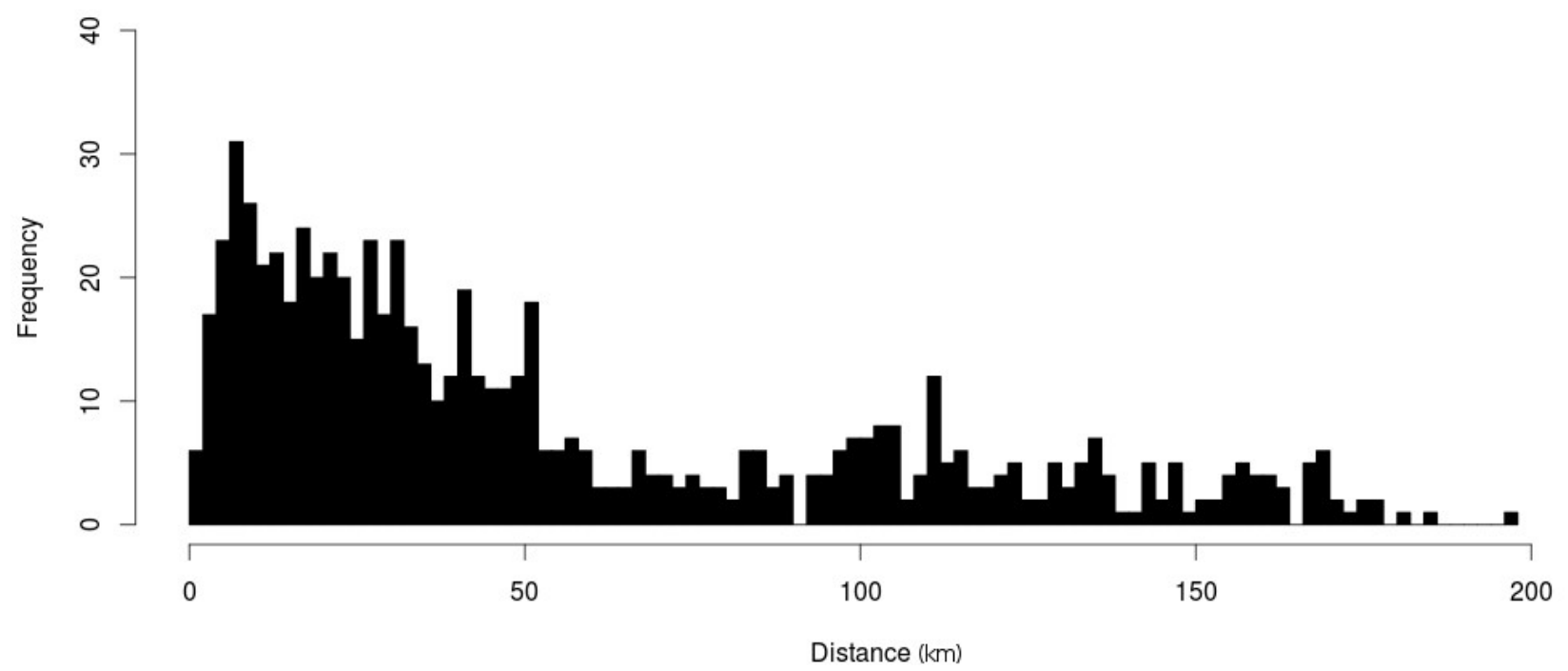

579 Figure 4. Frequency distribution of dispersal distances obtained for O. melanura from all 580 simulations. 


\begin{tabular}{|c|c|c|c|c|}
\hline Source & Df & ss & Fvalue & \\
\hline $\mathrm{T}$ & 1 & 2.63 & 3.027 & \\
\hline D & 3 & 72.63 & 8.41 & * \\
\hline Z & 2 & 177.76 & 146.975 & 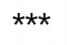 \\
\hline$T * D$ & 3 & 2.7 & 1.64 & \\
\hline$T^{\star} Z Z$ & 2 & 1.73 & 1.434 & \\
\hline$D^{\star} Z$ & 6 & 17.27 & 4.76 & 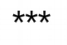 \\
\hline$T * D * Z$ & 6 & 3.29 & 0.908 & \\
\hline Residual & 696 & 420.89 & & \\
\hline
\end{tabular}

581 Table 1. ANOVA on dispersal distances: $\mathrm{Df}=$ degrees of freedom, $\mathrm{SS}=$ sum of squares, $\mathrm{T}=$ dispersal 582 duration, $\mathrm{D}=$ release depth range, $\mathrm{Z}=$ release $\mathrm{zone}, *=\mathrm{p}<0.05, * * *=\mathrm{p}<0.001$. 

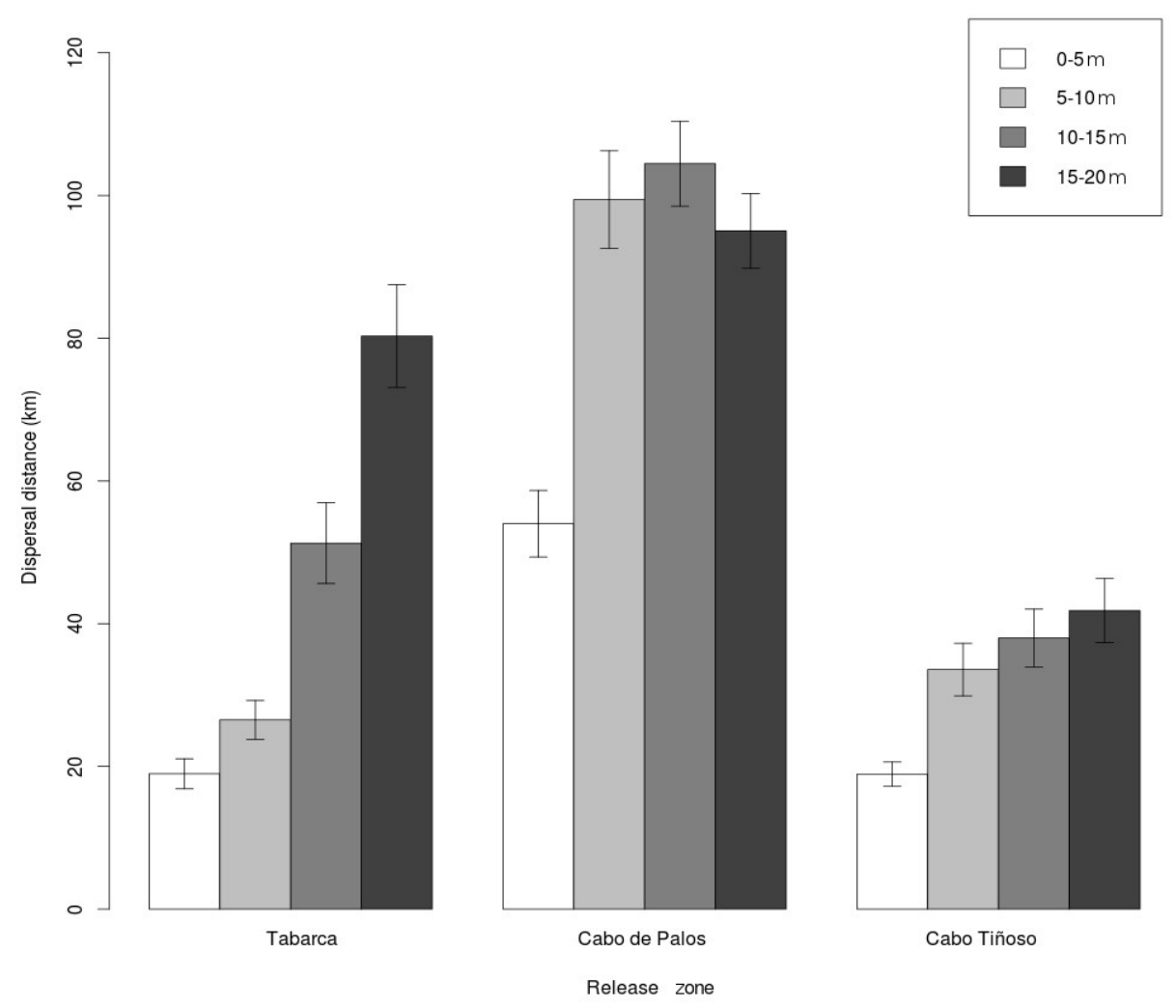

583 Figure 5. Dispersal distance (mean \pm SE) for all combinations of release zone and release depth 584 range. 

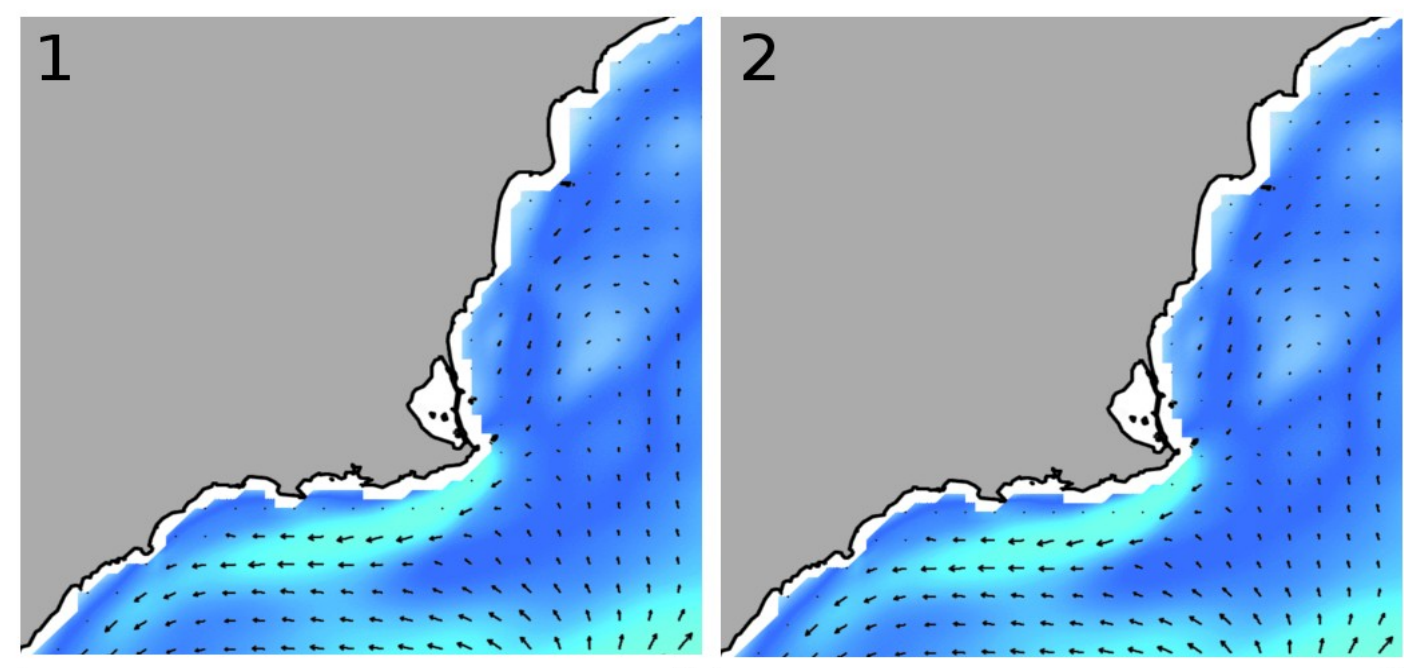

$\mathrm{m} / \mathrm{s}$

0.3

0.25

0.2

0.15

0.1

0.05
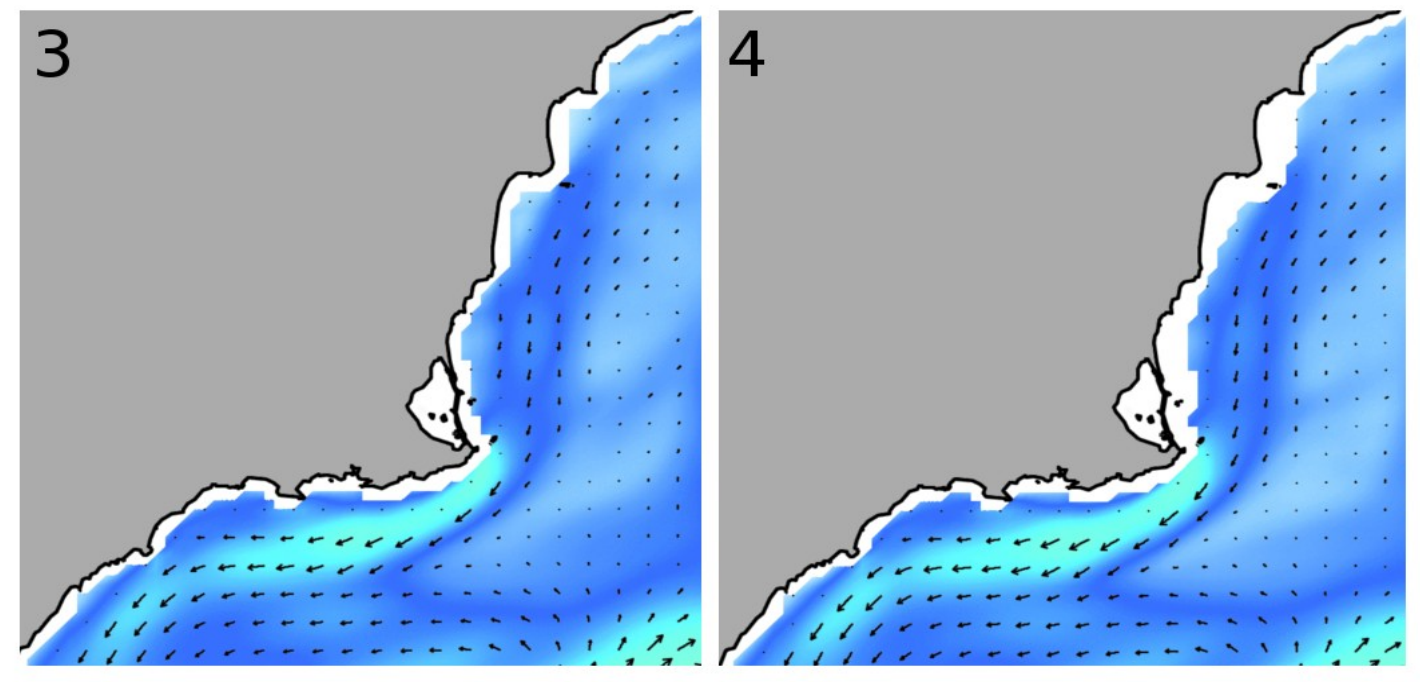

$\mathrm{m} / \mathrm{s}$

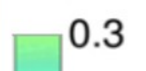

0.25

0.2

0.15

0.1

0.05

0
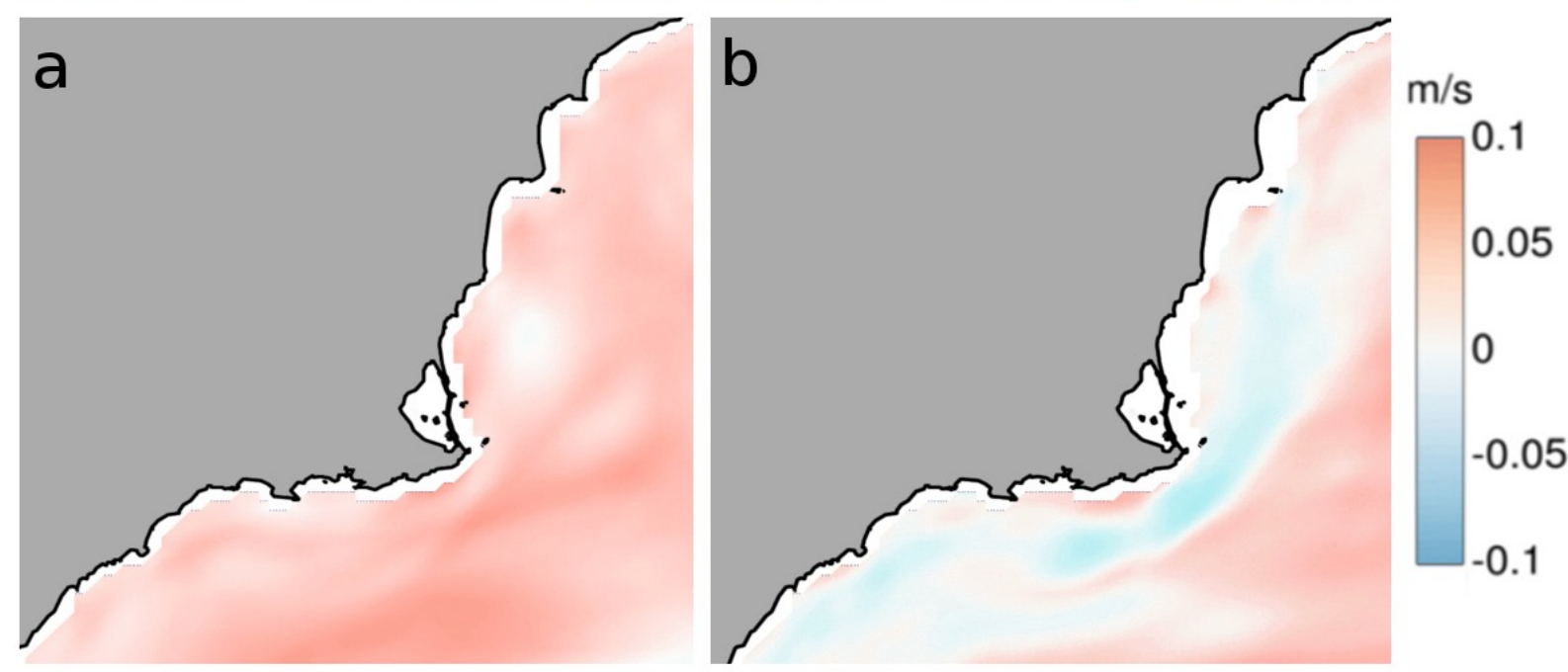

585 Figure 6. (1-4) Maps of average current velocities over the simulation period June $21^{\text {st }}-$ July $15^{\text {th }}$ 5862013 at different depth: 5 m (1), 10 m (2), 15 m (3) and 20 m (4). (a and b) Maps of difference in 587 average current velocity between $0 \mathrm{~m}$ and $10 \mathrm{~m}$ (a) and between $10 \mathrm{~m}$ and $20 \mathrm{~m}$ (b) over the same 588 time period: positive values (red colours) indicate that currents at the upper layer were faster than 589 deeper currents; negative values (blue colours) indicate the opposite. 


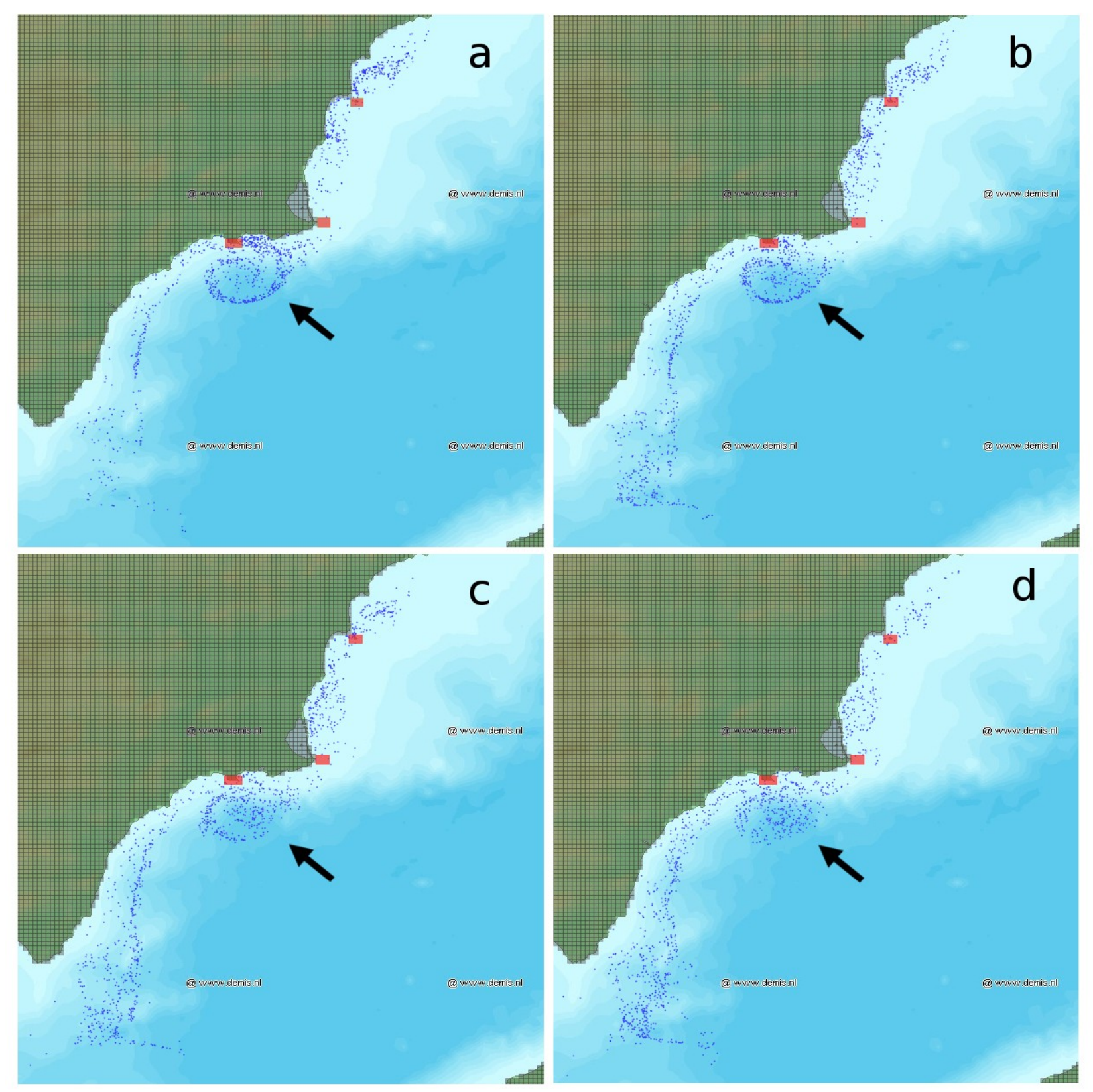

590 Fig 7. Last steps of larval dispersal simulations from 3 release zones (MPAs, red rectangles) and 591 daily release from June $21^{\text {st }}$ to July $2^{\text {nd }}$. Each panel corresponds to a different release depth: $5 \mathrm{~m}$ (a), $59210 \mathrm{~m}$ (b), $15 \mathrm{~m}$ (c) and $20 \mathrm{~m}$ (d). Black arrows indicate the position of one of the coastal eddies 593 responsible of particle trapping in shallower waters. Note the decreasing density of particles inside 594 the eddy and the increasing abundance of particles in the south of the domain from (a) to (d). 


\begin{tabular}{|c|c|c|c|c|c|c|c|c|c|c|c|c|c|c|c|}
\hline \multirow{2}{*}{$\begin{array}{c}\text { Ichthyop } \\
\text { run }\end{array}$} & \multicolumn{5}{|c|}{ Release zones } & \multirow{2}{*}{$\begin{array}{l}\text { Mantel's } \\
\text { test }\end{array}$} & \multirow{2}{*}{ pvalue } & \multirow{2}{*}{$\begin{array}{c}\text { Ichthyop } \\
\text { Run }\end{array}$} & \multicolumn{5}{|c|}{ Release zones } & \multirow{2}{*}{$\begin{array}{c}\text { Mantel's } \\
\text { Test }\end{array}$} & \multirow{2}{*}{ pvalue } \\
\hline & 1 & 2 & 3 & 4 & 5 & & & & 1 & 2 & 3 & 4 & 5 & & \\
\hline 1 & 01 & L2 & M1 & M2 & 02 & 0.3436 & 0.1191 & 26 & L2 & L5 & M2 & L9 & 02 & 0.455 & 0505 \\
\hline 2 & L3 & M1 & L6 & L9 & $\mathrm{O} 2$ & 0.0721 & 377 & 27 & L1 & M1 & L6 & L7 & L8 & -0.3424 & .9102 \\
\hline 3 & L1 & L2 & L5 & L9 & 02 & 0.496 & 0.0381 & 28 & 01 & L2 & L3 & M2 & L9 & 0.428 & 0.0313 \\
\hline 4 & 01 & L2 & L5 & M2 & 02 & 0.4435 & 056 & 29 & L1 & L3 & M1 & L6 & L8 & -0.3115 & .8969 \\
\hline 5 & L1 & M1 & L6 & L9 & 02 & 0.0932 & 18 & 30 & L1 & L3 & M1 & $\mathrm{L} 4$ & L9 & -0.1929 & 7006 \\
\hline 6 & $\mathrm{~L} 2$ & M1 & L5 & L6 & L9 & -0.0785 & 5457 & 31 & L1 & $\mathrm{L} 2$ & L5 & L8 & $\mathrm{O} 2$ & 0.3561 & .1078 \\
\hline 7 & 01 & L4 & M2 & L8 & 02 & 0.2379 & 013 & 32 & M1 & L5 & L6 & L7 & $\mathrm{O} 2$ & -0.0554 & 5673 \\
\hline 8 & L1 & L5 & L6 & M2 & L7 & -0.1127 & 623 & 3 & L1 & L2 & L3 & M2 & L7 & 0.078 & 3683 \\
\hline 9 & L1 & L3 & M1 & L4 & L8 & -0.3411 & 44 & 34 & L5 & L6 & M2 & L7 & L9 & .0607 & 3873 \\
\hline 10 & 01 & L1 & M1 & L4 & L5 & -0.2326 & 645 & 3 & L1 & L3 & M1 & L7 & $\mathrm{O} 2$ & 0.0037 & .4877 \\
\hline 11 & 01 & L1 & L3 & L6 & M2 & -0.081 & 305 & 36 & L3 & L4 & L7 & L9 & 02 & .1683 & 2804 \\
\hline 12 & 01 & L2 & L3 & L4 & L7 & -0.1017 & 17 & 37 & 01 & L2 & L3 & M1 & L6 & -0.1062 & .5975 \\
\hline 13 & 01 & L3 & L4 & L5 & M2 & & & & 01 & L2 & L5 & L6 & L7 & & 068 \\
\hline 14 & $\mathrm{~L} 1$ & L3 & M1 & L5 & L6 & -0 & 34 & 39 & L1 & L3 & L6 & L7 & $\mathrm{O} 2$ & 0.2136 & .2255 \\
\hline 15 & $\mathrm{~L} 1$ & L4 & L5 & L9 & 02 & & & & L2 & L4 & L7 & L8 & L9 & 0.1435 & .285 \\
\hline 16 & 01 & L1 & L4 & L7 & L8 & -0.0748 & 87 & 4 & L1 & L2 & L4 & L5 & M2 & 0.2217 & 1865 \\
\hline 17 & L1 & $\mathrm{L} 2$ & M1 & L5 & L9 & -0.0378 & & & L2 & M2 & L7 & L9 & $\mathrm{O} 2$ & 0.3952 & 0.0832 \\
\hline 18 & $\mathrm{~L} 2$ & L3 & M2 & L7 & 02 & 4 & 46 & 43 & 01 & L1 & M2 & L8 & 02 & 0.2395 & 192 \\
\hline 19 & 01 & L1 & L3 & M1 & L7 & -0.2599 & 63 & & 01 & L4 & L5 & L6 & L8 & 0.1763 & 0.2584 \\
\hline 20 & 01 & L2 & L6 & L7 & L8 & 0.0212 & 75 & 45 & L1 & L2 & L3 & M1 & M2 & 0.0204 & .386 \\
\hline 21 & 01 & L2 & M1 & L4 & M2 & -0.0833 & & & L4 & L5 & L6 & L6 & M2 & -0.068 & .597 \\
\hline 22 & L1 & L3 & $\mathrm{L} 4$ & L7 & L9 & -0.1178 & & r & L1 & L4 & L5 & L6 & $\mathrm{O} 2$ & 0.2415 & .1865 \\
\hline 23 & 01 & M1 & L7 & L9 & 02 & 0.0043 & 801 & 48 & L1 & $\mathrm{L} 2$ & L3 & L6 & M2 & 0.205 & .1882 \\
\hline 24 & L1 & $\mathrm{L} 2$ & L3 & L4 & L9 & & & 49 & L1 & L2 & L3 & $\mathrm{L} 4$ & L8 & -0.1286 & 0.6768 \\
\hline 25 & L3 & $\mathrm{L} 4$ & L5 & M2 & L8 & -0.0635 & 0.5914 & 50 & L3 & M1 & L5 & L7 & L8 & -0.3173 & 0.8755 \\
\hline
\end{tabular}

596 Table S1. Results from the first set of (50) Mantel's correlations between the settler distribution 597 obtained from otolith chemical analysis and the ones obtained from Ichthyop simulations. Rows 598 highlighted in red indicate significant Mantel's correlation. 


\begin{tabular}{|c|c|c|c|c|c|c|c|c|c|c|c|c|c|c|c|}
\hline \multirow{2}{*}{$\begin{array}{c}\text { Ichthyop } \\
\text { Run }\end{array}$} & \multicolumn{5}{|c|}{ Release zones } & \multirow{2}{*}{$\begin{array}{c}\text { Mantel's } \\
\text { Test }\end{array}$} & \multirow{2}{*}{ pvalue } & \multirow{2}{*}{$\begin{array}{c}\text { Ichthyop } \\
\text { Run }\end{array}$} & \multicolumn{5}{|c|}{ Release zones } & \multirow{2}{*}{$\begin{array}{c}\text { Mantel's } \\
\text { Test }\end{array}$} & \multirow{2}{*}{ pvalue } \\
\hline & 1 & 2 & 3 & 4 & 5 & & & & 1 & 2 & 3 & 4 & 5 & & \\
\hline $1^{*}$ & L1 & L2 & L5 & L9 & $\mathrm{O} 2$ & 0.496 & 0.0366 & 29 & $\mathrm{O} 1$ & L2 & L3 & L9 & $\mathrm{O} 2$ & 0.4319 & 0.0715 \\
\hline $2^{*}$ & 01 & L2 & L3 & M2 & L9 & 0.428 & 0.0305 & 30 & 01 & L2 & L5 & M2 & L9 & 0.3033 & 0.0935 \\
\hline 3 & $\mathrm{~L} 2$ & L5 & M2 & L9 & $\mathrm{O} 2$ & 0.455 & 0.0508 & 31 & 01 & L2 & L5 & L9 & $\mathrm{O} 2$ & 0.4746 & 0.0493 \\
\hline 4 & $\mathrm{O} 1$ & L2 & L5 & M2 & $\mathrm{O} 2$ & 0.4435 & 0.0553 & 32 & $\mathrm{O} 1$ & L2 & M2 & L9 & $\mathrm{O} 2$ & 0.5395 & 0.0263 \\
\hline 5 & 01 & L1 & L2 & L3 & L5 & 0.1256 & 0.3005 & 33 & $\mathrm{O} 1$ & L3 & L5 & M2 & L9 & 0.0299 & 0.4113 \\
\hline 6 & 01 & L1 & L2 & L3 & M2 & 0.0746 & 0.3724 & 34 & $\mathrm{O} 1$ & L3 & L5 & M2 & $\mathrm{O} 2$ & 0.3119 & 0.1431 \\
\hline 7 & 01 & L1 & L2 & L3 & L9 & 0.2909 & 0.1248 & 35 & 01 & L3 & L5 & L9 & $\mathrm{O} 2$ & 0.2819 & 0.1525 \\
\hline 8 & 01 & L1 & L2 & L3 & $\mathrm{O} 2$ & 0.456 & 0.0572 & 36 & 01 & L3 & M2 & L9 & $\mathrm{O} 2$ & 0.2654 & 0.168 \\
\hline 9 & $\mathrm{O} 1$ & L1 & L2 & L5 & M2 & 0.2317 & 0.2046 & 37 & $\mathrm{O} 1$ & L5 & M2 & L9 & $\mathrm{O} 2$ & 0.3146 & 0.1343 \\
\hline 10 & 01 & L1 & L2 & L5 & L9 & 0.2925 & 0.1147 & 38 & L1 & L2 & L3 & L5 & M2 & 0.1105 & 0.3186 \\
\hline 11 & 01 & L1 & L2 & L5 & $\mathrm{O} 2$ & 0.5526 & 0.0218 & 39 & L1 & L2 & L3 & L5 & L9 & 0.1623 & 0.2381 \\
\hline 12 & 01 & L1 & L2 & M2 & L9 & 0.3055 & 0.1093 & 40 & L1 & $\mathrm{L} 2$ & L3 & L5 & $\mathrm{O} 2$ & 0.4348 & 0.0713 \\
\hline 13 & 01 & L1 & L2 & M2 & $\mathrm{O} 2$ & 0.4011 & 0.0788 & 41 & L1 & L2 & L3 & M2 & L9 & 0.1774 & 0.2359 \\
\hline 14 & 01 & L1 & L2 & L9 & $\mathrm{O} 2$ & 0.5974 & 0.0147 & 42 & L1 & L2 & L3 & M2 & $\mathrm{O} 2$ & 0.4319 & 0.0784 \\
\hline 15 & 01 & L1 & L3 & L5 & M2 & -0.019 & 0.4882 & 43 & L1 & L2 & L3 & L9 & $\mathrm{O} 2$ & 0.4416 & 0.0708 \\
\hline 16 & $\mathrm{O} 1$ & L1 & L3 & L5 & L9 & 0.0423 & 0.4072 & 44 & L1 & L2 & L5 & M2 & L9 & 0.2966 & 0.0891 \\
\hline 17 & 01 & L1 & L3 & L5 & $\mathrm{O} 2$ & 0.6271 & 0.0129 & 45 & L1 & L2 & L5 & M2 & $\mathrm{O} 2$ & 0.5146 & 0.0235 \\
\hline 18 & 01 & L1 & L3 & M2 & L9 & 0.2089 & 0.2019 & 46 & L1 & L2 & M2 & L9 & $\mathrm{O} 2$ & 0.4851 & 0.0407 \\
\hline 19 & $\mathrm{O} 1$ & L1 & L3 & M2 & $\mathrm{O} 2$ & 0.297 & 0.1496 & 47 & L1 & L3 & L5 & M2 & L9 & -0.0696 & 0.5995 \\
\hline 20 & 01 & L1 & L3 & L9 & $\mathrm{O} 2$ & 0.415 & 0.0865 & 48 & L1 & L3 & L5 & M2 & $\mathrm{O} 2$ & 0.2664 & 0.1912 \\
\hline 21 & 01 & L1 & L5 & M2 & L9 & 0.1425 & 0.268 & 49 & L1 & L3 & L5 & L9 & $\mathrm{O} 2$ & 0.2682 & 0.2013 \\
\hline 22 & $\mathrm{O} 1$ & L1 & L5 & M2 & $\mathrm{O} 2$ & 0.4267 & 0.0778 & 50 & L1 & L3 & M2 & L9 & $\mathrm{O} 2$ & 0.2645 & 0.2013 \\
\hline 23 & 01 & L1 & L5 & L9 & $\mathrm{O} 2$ & 0.3236 & 0.1096 & 51 & L1 & L5 & M2 & L9 & $\mathrm{O} 2$ & 0.3161 & 0.1745 \\
\hline 24 & $\mathrm{O} 1$ & L1 & M2 & L9 & $\mathrm{O} 2$ & 0.333 & 0.116 & 52 & L2 & L3 & L5 & M2 & L9 & 0.3097 & 0.0897 \\
\hline 25 & 01 & L2 & L3 & L5 & M2 & 0.2502 & 0.1466 & 53 & L2 & L3 & L5 & M2 & $\mathrm{O} 2$ & 0.4394 & 0.0675 \\
\hline 26 & $\mathrm{O} 1$ & L2 & L3 & L5 & L9 & 0.1346 & 0.3001 & 54 & L2 & L3 & L5 & L9 & $\mathrm{O} 2$ & 0.4645 & 0.0566 \\
\hline 27 & 01 & L2 & L3 & L5 & $\mathrm{O} 2$ & 0.4198 & 0.0628 & 55 & L2 & L3 & M2 & L9 & $\mathrm{O} 2$ & 0.4199 & 0.0795 \\
\hline 28 & 01 & L2 & L3 & M2 & $\mathrm{O} 2$ & 0.5687 & 0.0158 & 56 & L3 & L5 & M2 & L9 & $\mathrm{O} 2$ & 0.3146 & 0.1821 \\
\hline
\end{tabular}

600 Table S2. Results from the second set of (56) Mantel's correlations between the settler distribution 601 obtained from otolith chemical analysis and the ones obtained from Ichthyop simulations. Rows 602 highlighted in red indicate significant Mantel's correlation. The sign '*' indicates the two runs 603 resulted statistically significant in the previous analysis. 